\title{
ANALISIS PENGARUH FAKTOR- FAKTOR PRODUKSI TERHADAP PENDAPATAN USAHATANI BAWANG MERAH DI DESA LAPANDEWA MAKMUR KECAMATAN LAPANDEWA KABUPATEN BUTON SELATAN
}

\author{
Wa Ode Al Zarliani \\ Program Studi Agribisnis Fakultas Peranian \\ Universitas Muhammadiyah Buton \\ Jin. Betoambari No. 36 Baubau \\ e-mail: waodealzalian@yahoo.com
}

\begin{abstract}
This research was conducted in Lapandewa Makmur Village of Lapandewa sub district of South Buton Regency, which takes place from June to July 2015. The aims of this research were : 1) to know what the area of land, seed, fertilizer, tanager labor simulates significant effect on farm incomes onion; 2) whether a land area is partially significant effect on farm incomes onion; 3) whether the seed is partially significant effect on farm incomes onion; 4) whether the fertilizer is partially significant effect on farm incomes onion; 5) whether the workforce is partially significant effect on farm incomes onion. The purpose of this research were ; 1) to determine the effect of land seed fertilizer, and labor on the farm income of onion, 2) to determine the effect of land on onion farming income, 3) to determine the effec ${ }^{1}$ of seed on onion farming income, 4) to determine the effect of fertilizer on onion farming income, 5) to determine the effect of employment on onion farming income. The population in this research is the overall farmers who cultivate plants of onion totaling 160 people. The determination of samples was done by simple random sampling, so that the number of samples obtained as many as 40 people. Furthermore, the data tabulated and analyzed by multiple linear regression analysis techniques to find out whether there is influence of socioeconomic characteristics of the respondent against the productivity of farmers in onion farming. The results of the analysis conducted regression equation $Y=628566.433+$ $5166123.665 X_{1}+0.0821 X_{2}+13.646 X_{3}-0.103 X_{4}+e$; The results of the research suggest that there as significant factors of production on onion farming income with adjusted $R$ Square at 0.514. This shows that the factors of production together have same influence on onion farming income of $51.4 \%$ and the remaining $48.6 \%$ is influenced by other factors. The value of significance for land area $\left(X_{1}\right)=0.026$; seeds $\left(X_{2}\right)=0.893$; fertilizer $\left(X_{3}\right)=0.024$; labor $\left(X_{4}\right)=0.854$. The value of the probability obtained each of these variables is smaller when compared to the significance or confidence level 5\%> or 0.05 then it can be said of the variable land area and fertilizer have significant effect, while labor $\left(X_{4}\right)$ and seeds $\left(X_{2}\right)$ have not significantly affect the revenues of onion farming.
\end{abstract}

Keywords: revenue, costs of production, cocoa

\begin{abstract}
Abstrak
Penelitian ini dilaksanakan di Desa Lapandewa makmur Kecamatan Lapandewa Kabupaten Buton Selatan yang berlangsung dari bulan Juni sampai dengan bulan Juli tahun 2015 . Permasalahan dalam penelitian ini adalah 1) apakah luas lahan, bibit, pupuk, tanage kerja
\end{abstract}


secara simultas berpengaruh signifikan terhadap pendapatan usahatani bawang merah, 2) apakah luas lahan berpengaruh signifikan terhadap pendapatan usahatani bawang merah, 3) apakah bibit secara parsial berpengaruh signifikan terhadap terhadap pendapatan usahatani bawang merah, 4) apakah pupuk secara parsial berpengaruh signifikan terhadap pendapatan usahatani bawang merah, 5) apakah tenaga kerja secara parsial berpengaruh signifikan terhadap pendapatan bawang merah. Tujuan penelitian ini adalah 1) untuk mengetahui pengaruh luas lahan, bibit, pupuk dan tenaga kerja terhadap pendapatan usahatani bawang merah, 2) untuk mengetahui pengaruh luas lahan terhadap pendapatan usahatani bawang merah, 3) untuk mengetahui pengaruh bibit terhadap pendapatan usahatani bawang merah, 4) untuk mengetahui pengaruh pupuk terhadap pendapatan usahatani bawang merah 5) untuk mengetahui pengaruh tenaga kerja terhadap pendapatan usahatani bawang merah. Populasi dalam penelitian ini adalah keseluruhan petani yang mengusahakan tanaman bawang merah yang berjumiah 160 orang. Penentuan sampel dilakukan dengan metode acak sederhana (Simple random sampling) sehingga diperoleh jumlah sampel sebanyak 40 orang. Selanjutnya data ditabulasi dan dianalisis dengan teknik analisis regresi linear berganda untuk mengetahui ada tidaknya pengaruh karakteristik sosial ekonomi petani responden terhadap produktifitas pada usahatani bawang merah. Hasil analisis yang dilakukan diperoleh persamaan Regresi Y $=628566.433+5166123.665$ X1 -0,082 X2 + 13.646 X3 - 0,103 X4 + e. Hasil penelitian memberikan gambaran bahwa terdapat pengaruh faktor-faktor produksi terhadap pendapatan usahatani bawang merah dengan nilai adjusted $\mathrm{R}$ Square sebesar 0,514. Hal ini menunjukan bahwa faktor-faktor produksi secara bersama-sama memberikan pengaruh terhadap pendapatan usahatani bawang merah sebesar 51,4\% dan selebihnya 48,6 \% dipengaruhi oleh faktor lain. Nilai signifikansi untuk luas lahan $\left(X_{1}\right)=0,026$, bibit $\left(X_{2}\right)=0,893$, pupuk $\left(X_{3}=\right.$ 0,024 , Tenaga kerja $\left(\mathrm{X}_{4}\right)=0,854$. Nilai probabilitas yang diperoleh masing-masing variabel tersebut lebih kecil bila dibandingkan dengan signifikan atau taraf kepercayaan $\mathbf{5} \%$ atau 0,05 maka dapat dikatakan variabel luas lahan, pupuk, berpengaruh signifikan sedangkan tenaga kerja, $\left(\mathrm{X}_{4}\right)$ bibit, $\left(\mathrm{X}_{2}\right)$ tidak berpengaruh secara signifikan terhadap pendapatan usahatani bawang merah

Kata Kunci: Pendapatan, biaya produksi, kakao

\section{PENDAHULUAN}

Indonesia merupakan negara kepulauan yang memiliki daratan yang sangat luas sehingga mata pencaharian penduduk sebagian besar berada pada sektor pertanian. Oleh karena itu Indonesia dikenal sebagi negara agraris yang berarti negara yang mengandalkan sektor pertanian sebagai penopang pembangunan juga sebagai sumber mata pencaharian penduduknya. Sektor pertanian di Indonesia meliputi subsektor tanaman bahan makanan, subsektor hortikultura, subsektor perikanan, subsektor petemakan dan subsektor kehutanan. Pada tahap awal pembangunan, sektor pertanian merupakan penopang perekonomian. Dapat dikatakan demikian, karena pertanian membentuk proporsi yang sangat besar bagi devisa negara, penyedia lapangan kerja dan sumber pendapatan masyarakat.

Hal ini kemudian menjadikan sektor pertanian sebagai pasar yang potensial bagi produk-produk dalam negeri baik untuk barang produksi maupun barang konsumsi, terutama produk yang dihasilkan oleh subsector tanaman bahan makanan. Subsektor pertanian terus dituntut untuk berperan dalam perekonomian nasional melalui pembentukan Produk Domestik Bruto (PDB), perolehan devisa, penyediaan pangan dan bahan baku industri, 
pengentasan kemiskinan, penyediaan lapangan kerja dan peningkatan pendapatan masyarakat.

Sektor petanian pangan biasanya diusahakan oleh rakyat kecil, salah satu koinoditas tanaman pangan yaitu bawang merah. Bawang merah termasuk dari sekian banyak koinoditas pertanian yang menjadi perhatian. Hal ini dikarenakan bawang merah merupakan komoditas unggulan yang mempunyai nilai ekonomi, sehingga banyak dibudidayakan di Indonesia. Bawang merah banyak digunakan sebagai bumbu masakan. Bawang merah juga dibutuhkan untuk keperluan ekspor.

Meningkatnya jumlah penduduk, pendapatan penduduk dan kesadaran gizi masyarakat, akan mendorong meningkatnya permintaan produk, terutama produk hortikultura baik di pasar dalam maupun luar negeri. Peningkatan jumlah tersebut dibutuhkan sebagai bumbu masak untuk melezatkan makanan, tambahan gizi serta manfaat lain yang dimiliki bawang merah.

Peningkatan konsumsi bawang merah dalam negeri harus diimbangi dengan peningkatan produksi dalam negeri, baik kuantitas maupun kualitas, dengan cara intensifikasi maupun ekstensifikasi. Kabupaten Buton Selatan sebagai salah satu sentra penghasil bawang merah produksinya mengalami perubahan dari tahun ke tahun hal ini di karenakan perubahan luas lahan tanaman dan produktivitas.

Berdasarkan data statistik Kabupaten Buton, pada Tahun 2012 luas panen bawang merah sebesar 39 Hektar dengan jumlah produksi yang dihasilkan sebesar 1.603 Kwintal/Hektar dan produktivitas yang dihasilkan sebesar 41,03 Kwintal/hektar. Pada tahun 2013 luas panen sebesar 33 Hektar, jumlah produksi yang dihasilkan 202 Kwintal, dengan produktivitas sebesar 6,12 Kwintal/Hektar. Kondisi ini menunjukan bahwa terjadi penurunan luas panen sebesar 6 Hektar. Sehingga terjadi penurunan produktivitas yang sangat signifikan sebesar 34,98 Kwintal/Hektar. Kondisi adanya penurunan luas panen, produksi dan produktivtas juga dialami oleh beberapa Kecamatan yang ada di Kabupaten Buton.

Salah satu Kecamatan yang ada di Kabupaten Buton Selatan yang melakukan kegiatan usahatani bawang merah adalah Kecamatan Lapandewa yang memiliki potensi keadaan alam yang cocok untuk pengembangan usahatani bawang merah. Hal ini berdasarkan data statistik Kabupaten Buton menunjukan bahwa sebagian besar luas panen tanaman bawang merah berada di Kecamatan Lapandewa sebesar 22 Hektar.

Berdasarkan data statistik Kabupaten Buton Tahun 2014, luas panen tanaman bawang merah sebesar 22 Hektar, jumlah produksi yang dihasilkan sebesar 913 Kwintal dengan produktivitas yang dihasilkan sebesar 41,50 Kwintal/Hektar sedangkan pada tahun 2013 luas panen sebesar 14 hektar, jumlah produksi yang dihasilkan sebesar 65 Kwintal dengan dengan tingkat pencapaian produktivitas sebesar 4,65 Kwintal/Hektar. Kondisi ini menunjukan terjadinya penurunan luas panen, produksi dan produktivitas yang sangat signifikan

Berfluktuasinya produksi bawang merah dalam kontribusi produksi bawang merah, disebabkan belum optimalnya penggunaan faktor produksi. Faktor produksi yang dimaksud adalah luas lahan, jumlah bibit, jumlah pupuk, dan jumlah pestisida yang digunakan dalam budidaya bawang merah.

Adanya penurunan jumlah produksi tersebut menunjukan bahwa produksi bawang merah belum dapat memenuhi kebutuhan dalam negeri karena petani dihadapkan oleh beberapa kendala, diantaranya adalah lahan pertanian yang dimiliki petani relatif sempit sehingga produksinya kecil dan tidak efisien dalam pengelolaan yang dilakukan secara tradisional serta terjadinya fluktuasi harga yang tidak menentu. Turun naiknya harga tidak bisa dipastikan tergantung dari kondisi pasar. Setiap daerah pada umumnya memiliki kondisi 
pasar yang berbeda-beda sehingga dapat mengakibatkan perbedaan harga antara daerah satu dengan daerah yang lainnya.

Usahatani bawang merah diupayakan untuk mendapatkan keuntungan yang maksimum. Mengingat hal ini, maka petani bawang merah harus berusaha memperhitungkan aspek ekonomi dalam usahataninya, sehingga biaya yang dikeluarkan dan keuntungan yang diperoleh berdasarkan skala usahanya diketahui. Tujuan yang hendak dicapai serta kendala yang dihadapi merupakan faktor penentu bagi petani bawang merah untuk mengambil keputusan dalam usahanya.

Diantara berbagai faktor produksi dari usaha pertanian bawang merah tersebut diperkirakan terdapat faktor produksi yang sangat menentukan dalam usaha pertanian bawang merah yang meliputi luas lahan, pupuk, bibit, Tenaga Keja (Hari Orang Kerja).

Penggunaan pupuk yang tepat dalam artian sesuai dengan dosis yang dianjurkan dan waktu yang tepat akan memberikan pengaruh positif terhadap tanaman bawang merah yan dapat meningkatkan hasil produksi sehingga pada akhirnya pendapatan petani meningkat, penjelasan tersebut sejalan dengan pendapat Siregar, (1992) bahwa untuk terselenggaranya pemupukan tanaman secara baik dan efektif, maka yang perlu diperhatikan adalah dosis yang digunakan, cara pemberian pupuk, waktu yang tepat pemberian pupuk dan keadaan air pada saat pemberian pupuk, sebaliknya bila pemberian pupuk tidak tepat akan mengakibatkan keseimbangan unsur hara di dalam tanah tidak terkontrol dan akibatnya produktivitas lahan akan menurun.

Disisi lain, bila ditinjau dari hasil produksi Kabupaten Buton dari tahun 2011 - 2013 produksi bawang merah mengalami fluktuasi dalam produksinya. Beberapa faktor yang diduga dapat mempengaruhi hasil produksi bawang merah antara lain : luas lahan, biaya tenaga kerja, varietas bibit, biaya pembelian pupuk dan biaya produksi lainnya adalah merupakan faktor yang harus diperhatikan dalam usaha tani bawang merah.

Berdasarkan latar belakang diatas maka yang menjadi masalah dalam penelitian ini adalah sebagai berikut: (1) apakah luas lahan, bibit, pupuk, dan tenaga kerja secara bersamasama berpengaruh signifikan terhadap pendapatan usahatani bawang merah di desa Lapandewa Makmur, (2) apakah luas lahan berpengaruh signifikan terhadap pendapatan usahatani bawang merah di Desa Lapandewa Makmur Kecamatan Lapandewa, (3) apakah bibit berpengaruh signifikan terhadap pendapatan usahatani bawang merah di Desa Lapandewa Makmur Kecamatan Lapandewa, (4) apakah pupuk berpengaruh signifikan terhadap pendapatan usahatani bawang merah di Desa Lapandewa Makmur Kecamatan Lapandewa, (5) apakah tenaga kerja berpengaruh signifikan terhadap pendapatan usahatani bawang merah di Desa Lapandewa Makmur Kecamatan Lapandewa

Tujuan yang dicapai dalam penelitian ini adalah: (1) untuk mengetahui pengaruh luas lahan, bibit, pupuk, dan tenaga kerja secara bersama-sama berpengaruh signifikan terhadap pendapatan usahatani bawang merah di Desa Lapandewa Makmur Kecamatan Lapandewa, (2) untuk mengetahui pengaruh luas lahan terhadap pendapatan usahatani bawang merah di Desa Lapandewa Makmur Kecamatan Lapandewa, (3) untuk mengetahui pengaruh bibit terhadap pendapatan usahatani bawang merah di Desa Lapandewa Makmur Kecamatan Lapandewa, (4) untuk mengetahui pengaruh pupuk terhadap pendapatan usahatani di Desa Lapandewa Makmur Kecamatan Lapandewa, (5) untuk mengetahui pengaruh tenaga kerja terhadap pendapatan usahatani di Desa Lapandewa Makmur Kecamatan Lapandewa

Manfaat penelitian adalah : (1) sebagai bahan pertimbangan bagi pemerintah maupun masyarakat yang berkaitan dalam mengambil kebijaksanaan dalam pengembangan dan peningkatan produksi bawang merah, (2) sebagai bahan masukan bagi petani bawang merah dalam usaha perbaikan tingkat pendapatan dan pola usahatani yang lebih efisien, (3) sebagai 
bahan studi dan referensi bagi mahasiswa yang berhubungan dengan penelitian ini, khususnya mahasiswa pertanian program studi agribisnis.

\section{METODE PENELITIAN}

Populasi adalah jumlah dari keseluruhan obyek yang diteliti (Arsyad dan Soeratno, 1999). Populasi mengacu pada keseluruhan kelompok orang, kejadian atau obyek yang ingin diinvestigasi oleh peneliti (Sekaran, 2006). Populasi sasaran dalam penelitian ini meliputi seluruh petani bawang merah di Desa Lapandewa Makmur yang berjumlah $160 \mathrm{KK}$.

Sampel adalah bagian dari populasi yang terdiri atas sejumlah anggota yang dipilih dari populasi (Sekaran, 2006). Penentuan besamya sampel untuk kebanyakan penelitian adalah lebih dari 30 dan kurang dari 500 dan Menurut Arikunto (1993) jika populasi diatas 100 orang maka dapat mengambil sampel 20\% - 25\% namun jika popolasi dibawah 100 orang maka mengambil sampel seluruhnya. Mengacu pada hal tersebut maka penelitian ini mengambil sampel sebanyak $25 \%$ dari populasi sehingga diperoleh sampel berjumlah 40 orang dengan pertimbangan keterbatasan waktu, tenaga dan biaya dalam penelitian.

Data yang dikumpulkan dalam penelitian ini terdiri dari data primer dan data sekunder. Data primer diperoleh secara langsung melalui wawancara secara langsung kepada responden dengan menggunakan daftar pertanyaan (kuesioner) yang telah dipersiapkan terlebih dahulu. Data sekunder diperoleh dari lembaga atau instansi dan dinas yang terkait dengan penelitian ini.

Variabel dalam penelitian ini meliputi: (1) Karakteristik petani : umur, tingkat pendidikan, jumlah tanggungan keluarga, pengalaman berusahatani, (2) Identitas usahatani: jumlah produksi, harga, penerimaan, jumlah pupuk, jumlah tenaga kerja, bibit, luas lahan, pendapatan, biaya produksi.

Analisis pendapatan usahatani bawang merah dianalisis berdasarkan status petani penggarap dan petani pemilik. Perhitungan penerimaan total biaya dan pendapatan usahtani dapat dituliskan secara matematis sebagai berikut:

$\mathrm{TR}=\mathrm{PxQ}$

$\mathrm{TC}=$ Biaya tetap + biaya variabel

$\mathrm{NI}=\mathrm{TR}-\mathrm{TC}$

Keterangan:

$\mathrm{TR}=$ Total penerimaan usahatani $(\mathrm{Rp})$

$\mathrm{TC}=$ Total biaya usahatani $(\mathrm{Rp})$

$\mathrm{NI}=$ Pendapatan Bersih (Rp)

$\mathrm{P}=$ Harga output $(\mathrm{Rp} / \mathrm{Kg})$

$\mathrm{Qi}=$ Jumlah output $(\mathrm{Kg})$

Untuk menguji hipotesis, diuji dengan analisis regresi linear berganda dengan rumus:

$\mathrm{Y}=\mathrm{a}+\mathrm{b} 1, \mathrm{X} 1+\mathrm{b} 2 \mathrm{X} 2+\mathrm{b} 3 \mathrm{X} 3+\mathrm{b} 4 \mathrm{X} 4+\mathrm{e}$

$\mathrm{Y}=$ Pendapatan bawang merah/ Ha X1 = Luas lahan $(\mathrm{Ha})$

$\mathrm{X} 2=\operatorname{bibit}(\mathrm{Kg})$

$\mathrm{X} 3=\operatorname{pupuk}(\mathrm{Kg})$

$\mathrm{X} 4$ = Tenaga kerja $(\mathrm{HKP})$

$\mathrm{a}=$ Intercept

b1, b2, b3, b4 = Koefisien Regresi 
Untuk menguji pengaruh variabel tersebut secara serempak, maka $\underline{r^{2} I k}$ digunakan uji $\mathrm{F}$ yakni :

F hitung $=(\backslash-r j i(n-k-\backslash)$

Keterangan :

$\mathrm{r}^{2}=$ Koefisien determinasi

$\mathrm{n}=$ Jumlah sampel

$\mathrm{k}=$ Derajat bebas pembilang

$\mathrm{n}-\mathrm{k}-1$ = Derajat bebas penyebut Kriteria uji hipotesis adalah :

Jika F hitung > F tabel maka tolak Ho atau terima Hi (Sudjana, 1988).

Untuk menguji secara parsial digunakan uji t dengan rumus sebagai berikut:

th $=$ bi / Sbi

Keterangan :

$\mathrm{bj}=$ Koefisien regresi

Dengan Kriteria uji:

Jika t hitung < tabel maka:

Ho diterima dan Hi ditolak

Jika t hitung > t tabel maka:

Ho ditolak dan Hi diterima

\section{PEMBAHASAN}

\section{Identitas Petani Responden}

Identitas petani responden atau karateristik petani merupakan salah satu faktor yang menentukan tingkat keberhasilan petani dalam melakukan kegiatan usahatani bawang merah. Identitas responden yang dimaksud adalah: umur, jumlah tanggungan keluarga, tingkat pendidikan, dan pengalaman berusahatani dalam melakukan usahatani bawang merah.

\section{a. Umur Responden}

Umur merupakan salah satu indicator yang mempengaruhi seseorang dalam berpikir dan bertindak. Umur yang akan lebih dinamis dan mudah menerima hal - hal yang baru sehingga akan berpengaruh dalam menentukan keberhasilan usahatani bawang merah yang dilakukan.

Berdasarkan hasil penelitian menunjukan bahwa sebagian besar petani responden berada pada kelompok umur produktif. Yaitu berkisar antara 33 - 54 Tahun. Untuk lebih jelas dapat dilihat pada Tabel 1

Tabel 1. Identitas petani berdasarkan kelompok umur produktif dan kurang produktif di Desa Lapandewa Makmur Tahun 2015.

\begin{tabular}{cccc}
\hline No & Umur (Tahun) & Jumlah (Orang) & Persentase (\%) \\
\hline 1. & $33-54$ & 28 & 70 \\
2. & $55-71$ & 12 & 30 \\
\hline & Jumlah & 40 & 100 \\
\hline
\end{tabular}

Tabel 1 nampak bahwa sebagian besar responden berada pada kisaran umur produktif 33 - 54 tahun berjumlah 28 orang atau $70 \%$ dan petani responden yang berada pada kelompok umur kurang produktif berjumlah 12 orang atau $30 \%$. Pengelompokan umur 
produktif dan kurang produktif. Menurut A. Soehardjo dan Dahlan Patong (1984) bahwa umur produktif manusia berkisar antara 15 sampai 54 tahun dan kurang produktif diatas 54 tahun. Kondisi tersebut menggambarkan bahwa petani yang ada di desa Lapandewa Makmur dapat bekerja secara maksimal dan dapat mengambil keputusan dengan pertimbangan yang matang dan petani yang berumur muda mengindikasikan berani mengambil resiko, dengan demikian maka diharapkan pencapaian produksi akan maksimal.

\section{b. Tingkat Pendidikan}

Latar belakang pendidikan yang dimiliki seseorang akan mempengaruhi petani dalam menganalisis suatu kegiatan yang akan dilakukakan terutama dalam pengambilan keputusan terkait dengan adanya berbagai altemastif keputusan yang harus diambil seorang petani dalam melakukakan kegiatan usahataninya Seseorang yang memiliki tingkat pendidikan yang lebih tinggi maka akan semakin baik dalam pengambilan keputusan dan bertindak

Kemampuan petani dalam berpikir dan mengelola usahataninya sangat dipengaruhi pula oleh tingkat pendidikannya. Makin tinggi tingkat pendidikan seseorang maka kemampuan mengelola usahataninya akan lebih baik karena mereka lebih luwes dan lebih dinamis dalam menyerap informasi serta menerapkan teknologi untuk meningkatkan produktifitas usahataninya. Untuk lebih jelas keadaan pendidikan petani responden dapat dilihat pada Tabel 2.

Tabel 2. Keadaan Tingkat Pendidikan Petani Responden di Desa Lapandewa Makmur Tahun 2015.

\begin{tabular}{|c|c|c|c|}
\hline No & Tingkat pendidikan (Tahun) & Jumlah (Orang) & Persentase (\%) \\
\hline 1. & Tdk sekolah & 6 & 15,00 \\
2. & SD & 24 & 60,00 \\
3. & SMP & 7 & 17,50 \\
4. & SMA & 3 & 7,50 \\
\hline & & 40 & 100,00 \\
\hline
\end{tabular}

Tabel 2 menunjukkan bahwa psebagian besar petani responden telah mengenyam pendidikan formal. Petani responden dengan tingkat pendidikan SD mendominasi dengan 23 orang atau $57,50 \%$, petani responden dengan tingkat pendidikan SMP berjumlah 7 orang atau $17,50 \%$, petani dengan tingkat pendidikan SMA berjumlah 3 orang atau $7,50 \%$. Keadaan ini menggambarkan bahwa perlu diadakan penyuluhan atau kegiatan pelatihan untuk menambah pengetahuan dan ketrampilan yang dimiliki oleh petani bawang merah sehingga dengan tingkat pendidikan yang sebagian besar hanya setingkat SD namun dengan adanya kegiatan tersebut, petani akan memiliki pengetahuan dan ketrampilan yang baik sehingga dapat membantu petani dalam melakukan dan mengelola kegiatan usahataninya sehingga makin lebih maju dan berkembang.

\section{c. Pengalaman Berusahatani}

Pengalaman berusahatani merupakan wahana belajar bagi seorang petani. Pengalaman berusahatani juga merupakan proses pendidikasn non formal yang diperoleh petani. Setiap melakukan kegiatan usahataninya. Dari pengalaman yang dilalui oleh seorang petani akan menjadi pengalaman berharga bagi petani sehingga akan selalu ada perubahan dari setiap keputusan yang diambil. Semakin lama seseorang dalam berusahatni maka akan makin memberikan pengaruh yang baik dan positif bagi petani dalam melakukakn kegiatan usahataninya. 
Berdasarkan hasil penelitian menunjukan bahwa sebagian besar petani responden telah memiliki pengalaman yang dapat dikategorikan berpengalaman. Untuk lebih jelasnya dapat dilihat pada Tabel 3.

Tabel 3. Keadaan Pengalaman Berusahatani Petani Responden di Desa Lapandewa Makmur Tahun 2015.

\begin{tabular}{cccr}
\hline No & $\begin{array}{c}\text { Pengalaman } \\
\text { berusahatani (Tahun) }\end{array}$ & $\begin{array}{c}\text { Jumlah } \\
\text { (Orang) }\end{array}$ & $\begin{array}{c}\text { Persentase } \\
(\%)\end{array}$ \\
\hline 1. & $5-10$ & 3 & 7,50 \\
2. & $>10$ & 37 & 92,5 \\
\hline & Jumlah & 40 & 100,00 \\
\hline
\end{tabular}

Tabel 3 menunjukkan bahwa sebagian petani responden memiliki pengalaman diatas 10 tahun. Dengan jumlah petani 37 orang atau 92\% dan yang memiliki pengalaman $5-10$ tahun berjumlah 3 orang atau 7,5\%. Kondisi ini menggambarkan bahwa sebagian besar petani responden yang ada di Desa Lapandewa Makmur dapat dikategorikan berpengalaman. Penjelasan tersebut sesuai dengan pendapat Soeharjo dahlan patong bahwa seorang petani dikatakan berpengalaman apabila telah menggeluti kegiatan usahataninya diatas 10 tahun dan dikategorikan cukup pengalaman apabila menggeluti kegiatan usahataninya berkisar antara 5-10 tahun. Dengan pengalaman yang dimil iki oleh petani tersebut dapat menambah pengetahuan dan ketrampilan dalam melakukan kegiatan usahataniya walaupun dari tingkat pendidikan sebagian besar tingkat SD. Dengan pengalaman yang telah dilaluinya diharapkan akan menjadi pelajaran untuk memperbaiki kegiatan usahatani yang dilakukan dan akan terus lebih baik sehingga produksi yang dihasilkan mencapai hasil produksi yang maksimal.

\section{d. Jumlah Tanggungan Keluarga}

Tanggungan keluarga adalah sejumlah orang yang tinggal dalam satu keluarga yang secara langsung jadi tanggungan kepala keluarga atau tidak serumah namun masih merupakan tanggungan kepala keluarga yang bersangkutan.

Tanggungan keluarga merupakan salah satu sumber daya manusia yang dapat dikembangkan untuk membantu kepala keluarga, utamanya anggota keluarga yang berusia produktif. Kepala keluarga dalam kedudukannya sebagai anggota masyarakat, termasuk sebagai petani, berusaha untuk memenuhi kebutuhan keluarganya dan tuntutan dari Iuar keluarganya. Makin besar tanggungan keluarga, makin besar pula usaha yang dilakukan untuk memenuhi kebutuhan keluarganya.

Jumlah tanggungan keluarga responden dalam penelitian ini berkisar antara 2 sampai 7 orang. Untuk lebih jelas tentang jumlah tanggungan keluarga responden dapat dilhat pada Tabel 4.

Tabel 4. Keadaan Jumlah Tanggungan Keluarga Petani Responden di Desa Lapandewa Makmur Tahun 2015.

\begin{tabular}{cccc}
\hline No & JumlahTanggungan (Tahun) & Jumlah (orang) & Persentase 1 (\%) \\
\hline 1. & $1-3$ & 14 & 35,00 \\
\hline 2. & $4-5$ & 17 & 42,50 \\
\hline 3. & $6-7$ & 9 & 22,50 \\
\hline & Jumlah & 40 & 100,00 \\
\hline
\end{tabular}


Tabel 4 menunjukkan bahwa sebagian besar memiliki jumlah tanggungan keluarga berkisar antara 4 - 5 jiwa dengan jumlah responden 17 Orang atau 42\%, petani yang memiliki jumlah tanggungan keluarga berkisar antara 2 - 3 orang berjumlah 14 orang atau 35\% dan petani responden yang memiliki jumlah tanggungan keluarga berkisar antara $6-7$ orang berjumlah 9 orang atau 22,50\%. Keadaan ini menggambarkan bahwa sebagian besar petani responden telah memiliki jumlah tanggungan keluarga yang dapat dikategorik sedang. Dengan jumlah tanggungan keluarga tersebut dapat membantu petani dalam melakukan kegiatan usahatninya dan dapat mengurangi biaya yang dikeluarkan oleh petani terkait dengan upah tenaga kerja luar keluarga yang harus dibayar pada saat melakukan kegiatan usahatani bawang merah. Jumlah tanggungan keluarga dapat bemilai positif bila jumlah tanggungan tersebut dapat menjadi tenaga kerja dan bekerja dengan maksimal membantu petani dalam melakukan kegiatan usahatani akan tetapi dapat juga bemilai negatif apabila jumlah tanggungan keluarga tersebut tidak bekerja secara maksimal membantu petanu dalam melakukan dan mengelolah usahataninya. Dengan jumlah tanggungan keluarga yang besar juga akan memberikan semangat kepada petani untuk bekerja lebih maksimal sehingga dapat membiayai segala kebutuhan keluarganya dan kegiatan usahataninya lebih berkembang.

\section{Deskripsi Usahatani}

Deskripsi usahatani merupakan gambaran keadaan usahatani petani responden dalam melakukan kegiatan atau aktivitas usahataninya. Deskripsi usahatani yang dimaksud antara lain: luas lahan garapan, jumlah produksi, biaya, harga penjualan.

\section{a. Luas Lahan Garapan}

Luas lahan garapan merupakan salah satu faktor produksi yang menentukan dan mempengaruhi jumlah produksi yang dihasilkan. Luas lahan yang dimiliki dan digarap oleh petani akan menentukan tingkat keberhasilan petani. Semakin luas lahan yang dimiliki akan semakin leluasa petani dalam mengelola dan menentukan penggunaan lahan makin banyak sarana produksi yang dihasilkan yang pada akhimya akan berdampak pada peningkatan hasil produksi yang dicapai.

Berdasarkan hasil penelitian menunjukan luas lahan yang dimiliki oleh petani bervariasi, dengan rata- rata luas lahan sebesar 0,3 hektar, dengan kisaran antara 0,15 - 0,5 Hektar. Untuk lebih jelasnya dapat dilihat pada Tabel 5 berikut :

Tabel 5. Keadaan Luas Lahan Garapan di Desa Lapandewa Makmur Kecamatan Lapandewa tahun 2015.

\begin{tabular}{cccr}
\hline No & Luas lahan (Tahun) & Jumlah (Orang) & Persentase (\%) \\
\hline 1 & $0,15-0,27$ & 23 & 57,500 \\
\hline 2. & $0,28-0,39$ & 7 & 17,50 \\
\hline 3. & $0,40-0,50$ & 10 & 25,00 \\
\hline & Jumlah & 40 & 100,00 \\
\hline
\end{tabular}


Tabel 5 menunjukkan bahwa petani yang memiliki luas lahan berkisar antara 0,15 0,27 Hektar berjumlah 23 orang, petani yang memiliki luas lahan $\mathbf{0 , 2 8}$ - $\mathbf{0 , 3 9}$ Hektar berjumlah 7 orang atau $\mathbf{1 7 , 7 0 \%}$ dan petani yang memiliki luas lahan 0,40 - 0,50 Hektar berjumlah $\mathbf{1 0}$ orang atau $\mathbf{2 5 \%}$. Kondisi tersebut menggambarkan sebagian besar petani memiliki luas lahan yang dikategorikan kecil bila dilihat dari kategori berdasarkan daerah hasil penenlitian. Dengan luas lahan yang dimiliki diharapkan para petani responden dapat melakukan kegiatan usahatani dengan memanfaatkan faktor-faktor produksi sesuai dengan anjuran sehingga akan menghasilkan produksi yang maksimal 3. Analisis Pengaruh Luas Lahan, Bibit, Pupuk, Tenaga kerja Terhadap Pendapatan Usahatani Bawang Merah.

Hasil perhitungan regresi berganda dengan menggunakan bantuan computer program SPSS version 19.00, menunjukan bahwa luas lahan, bibit, tenaga kerja, pupuk yang merupakan variabel bebas secara bersama- sama dan signifikan mempengaruhi pendapatan usahatani bawang merah (variabel terikat). Hal ini dapat dilihat pada hasil analisis yang dilakukan diperoleh nilai signifikansi sebesar 0,000. Nilai probabilitas tersebut tersebut lebih kecil bila dibandingkan dengan nilai signifikansi atau taraf kepercayaan $=(\operatorname{Sig}<\mathbf{0 , 0 5})$, dengan demikian dapat dikatakan bahwa Ho ditolak dan Ha yang diajukan diterima yang berarti bahwa luas lahan, bibit, pupuk dan tenaga kerja secara bersama-sama berpengaruh signifikan terhadap pendapatan usahatani bawang merah.

Hasil analisis regresi Linear Berganda diperoleh nilai koefisien determinasi Adjusted R Square sebesar 0,514 yang menunjukan besamya persentase pengaruh luas lahan, bibit, pupuk, tenaga kerja, secara simultan atau bersama-sama terhadap pendapatan usahatani bawang merah sebesar 51,4\% dan selebihnya 48,6\% (100\% - 51,4\%) dipengamhi oleh faktorfaktor lain diluar faktor-faktor penelitian.

Hasil Analisis Regresi Linear berganda yang dilakukan maka diperoleh nilai sig untuk mengetahui pengaruhluas lahan, bibit, pupuk dan tenaga kerja secara parsial terhadap pendapatan usahatani bawang merah. Maka Model regresi yang diperoleh adalah :

$\mathrm{Y}=628566.433+5166123.665 \mathrm{X},-0.082 \mathrm{X}_{2}+13.646 \mathrm{X}_{3}-0,103 \mathrm{X} 4+\mathrm{e}$

\section{SIMPULAN DAN SARAN}

\section{Simpulan}

Berdasarkan hasil analisis dan pembahasan yang telah dilakukan, maka dapat ditarik beberapa kesimpulan sebagai berikut:

(1) Hasil analisis regresi linear berganda menunjukan bahwa variabel luas lahan, bibit, pupuk tenaga kerja, secara bersama-sama berpengaruh signifikan terhadap pendapatan usahatani bawang merah. Pengaruh yang diberikan sebesar 51,4\% dan selebihnya 48,6\% dipengaruhi oleh faktor faktor yang lain diluar variabel penelitian, (2) Hasil analisis secara parsial diperoleh nilai t sebesar 2.324 (Sig sebesar 0,026). Nilai tersebut menunjukan bahwa luas lahan berpengaruh signifikan terhadap pendapatan usahatani bawang merah. Semakin luas lahan yang dikelola oleh petani maka makin besar produksi dan akan terimplementasi pada pendapatan yang diterima oleh petani, (3) Hasil analisis secara parsial diperoleh nilai t sebesar-136 (sig $=0,893)$. Nilai tersebut menunjukan bahwa penggunaan bibit tidak berpengaruh terhadap pada pendapatan usahatani bawang merah, (4) Hasil analisis secara parsial diperoleh nilai t sebesar 2,351 ( $\mathrm{sig}=0,024)$. Nilai tersebut menunjukan bahwa penggunaan pupuk berpengaruh signifikan terhadap pendapatan usahatani baw'ang merah, (5) Hasil analisis secara parsial diperoleh nilai t sebesar -185 (sig sebesar 0,854) Nilai tersebut menunjukan bahwa tenaga kerja tidak berpengaruh terhadap pendapatan. Hal ini disebabkan 
tenaga kerja tidak bekerja serius dan maksimal dalam melakukan kegiatan usahatani bawang merah.

\section{Saran}

Berdasarkan kesimpulan di atas, dapat dikemukakan beberapa saran sebagai berikut:

1. Diharapkan kepada para petani agar tetap melakukan kegiatan usahatani bawang merah lebih responsif dan tanggap terhadap adanya teknologi baru yang dapat meningkatkan produksi bawang merah.

2. Diharapkan kepada petani dalam melakukan kegiatan usahatani bawang merah perlu mengintensifkan kegiatan pemeliharaan sehingga dapat menghasilkan produksi yang optimal.

3. Kepada para penyuluh agar tetap melakukan kegiatan penyuluhan dan pelatihan yang lebih intensif, sehingga petani dapat meningkatkan pengetahuan dan keterampilannya.

\section{DAFTAR PUSTAKA}

Arsyad \& Soeratno, 1999. Metodologi Penelitian untuk Ekonomi dan Bisnis LPP AMP YKPN. Yogyakarta.

Anonim. 2014. Buton Dalam Angka. Buton

Budiono, 1992. Ekonomi Mikro. Badan Penerbit Fakultas Ekonomi.

Hemanto F. 1989. llmu Usahatani. Jakarta: Penebar Swadaya.

Sekaran, Uma, 2006. Resarch Methods for Business, Salemba Empat. Jakarta.

Hidayat, A, 2004. Budidaya bawang merah. Beberapa hasil penelitian di Kabupaten Brebes. Makalah disampaikan pada Temu Teknologi Budidaya Bawang Merah. Direktorat Tana. Sayuran dan Bio Farmaka, Brebes, 3 September 2004.

Komaruddin, 1985. Ensklopedi Manajemen. Alumni. Bandung.

Karsino, dkk, 1980. Pola tanam: Aplikasi teknologi Pertanian, intensifikasi tanaman Pangan dan Pola Usahatani. Sensus Pertanian 1983. Biro Pusat Statistik, Jakarta.

Mubyarto. 1986. Pengantar Ekonomi Pertanian. LP3ES. Jakarta.

Nurmalinda dan Suwandi. 1995. Potensi wilayah pengembangan bawang merah. Teknologi produksi bawang merah. Puslitbang Hortikultura. Badan Penelitian dan Pengembangan Pertanian. Jakarta.

Nazaruddin. 1999. Budidaya dan pengaturan panen sayuran dataran rendah. Penebar Swadaya.

Rismunandar. 1986. Membudidayakan lima jenis bawang. Penerbit Sinar Bam Bandung.

Rahmat Rukman. 1994. Bawang merah, budidaya dan pengolahan pasca panen. Penerbit Kanisius Yogyakarta.

Sutarya, R. dan G. Grubben, 1995. Pedoman bertanam sayuran dataran rendah. Gadjah Mada University Press. Prosea Indonesia - Balai Penel. Hortikultura Lembang.

Singgih Wibowo. 1991. Budidaya bawang putih, bawang merah, bawang Bombay. PT. Penebar Swadaya Jakarta.

Soekartawi, 1986. Ilmu Usahatani dan Penelitian untuk Pengembangan Petani Kecil. UI Press, Jakarta.

Sukirno, Sadono, 1985. Ekonomi Pembangunan. LPFE UI. Jakarta.

Soekartawi, 1993. Manajemen Pemasaran Dalam Bisnis Modern. Pustaka Sinar Harapan, Jakarta.

Soekartawi 2002. Analisis Usahatani. Penerbit Universitas Indonesia (UI- Press). Jakarta. 


\section{Media Agribisnis}

Vol. 2, Issue 2, November 2018

P-ISSN: 2527-8479

Widowati E. 2007. "Analisis Ekonomi Usahatani Padi Organik Di Kabupaten Sragen", Tests, MESP UNS, Surakarta. 